\title{
Retraction Note: Growth properties of Green-Sch potentials at infinity
}

Tao Zhao ${ }^{1}$ and Alexander Yamada Jr.. ${ }^{*^{*}}$

The original article can be found online at https://doi.org/10.1186/ s13661-014-0245-9

*Correspondence: yamadaayu71@yahoo.com ${ }^{2}$ Matematiska Institutionen, Stockholms Universitet, Stockholm, Sweden

Full list of author information is available at the end of the article

\section{Retraction note}

The Editors-in-Chief have retracted this article [1] because it shows evidence of peer review manipulation. In addition, the identity of the corresponding author could not be verified: Stockholms Universitet have confirmed that Alexander Yamada has not been affiliated with their institution. The authors have not responded to any correspondence regarding this retraction.

\footnotetext{
Author details

'School of Mathematics and Information Science, Henan University of Economics and Law, Zhengzhou, P.R. China. ${ }_{2}^{2}$ Matematiska Institutionen, Stockholms Universitet, Stockholm, Sweden.
}

\section{Publisher's Note}

Springer Nature remains neutral with regard to jurisdictional claims in published maps and institutional affiliations.

Published online: 22 January 2020

\section{References}

1. Zhao, T., Yamada, A.: Growth properties of Green-Sch potentials at infinity. Bound. Value Probl. 2014, 245 (2014). https://doi.org/10.1186/s13661-014-0245-9
(Q) The Author(s) 2020. This article is licensed under a Creative Commons Attribution 4.0 International License, which permits use sharing, adaptation, distribution and reproduction in any medium or format, as long as you give appropriate credit to the original author(s) and the source, provide a link to the Creative Commons licence, and indicate if changes were made. The images or other third party material in this article are included in the article's Creative Commons licence, unless indicated otherwise in a credit line to the material. If material is not included in the article's Creative Commons licence and your intended use is not permitted by statutory regulation or exceeds the permitted use, you will need to obtain permission directly from the copyright holder. To view a copy of this licence, visit http://creativecommons.org/licenses/by/4.0/. 